\title{
La reescritura del Himno homérico a Deméter en "Ira Demetrae" de Claribel Alegría
}

The rewriting of the Homeric Hymn to Demeter in "Ira Demetrae" by Claribel Alegría

Josefa Fernández Zambudio

Universidad de Murcia, España

pepifz@um.es

(iD https://orcid.org/0000-0002-2201-2921

\section{Resumen:}

En este artículo analizamos el poema "Ira Demetrae" de Claribel Alegría como renovación del género de los himnos. Delimitamos su relación con el relato proporcionado por Robert Graves en Los mitos griegos, y lo confrontamos con las fuentes antiguas, especialmente el Himno homérico a Deméter, el Himno II de la colección de Himnos homéricos, para buscar cuáles son las particularidades e innovaciones de la relectura de Alegría. Para ello, especificamos qué personajes y contenidos ha escogido la poeta, qué imágenes y detalles ha empleado, y qué objetivos ha alcanzado a través de ellos. Además, contextualizamos este poema en la obra de Claribel Alegría, buscando temas comunes. Esto nos permite ofrecer una visión completa sobre la tradición que renueva este poema, en el que hasta ahora no se ha detenido la crítica.

Palabras clave: Himno, Mito, Relectura, Deméter, Perséfone.

\section{Abstract:}

In this paper, we analyze Claribel Alegría's poem "Ira Demetrae" as a renewal of the genre of hymns. We delimit its relationships with the account provided by Robert Graves in The Greek Myths, and we compare with ancient sources, especially the Homeric Hymn to Demeter, Hymn II of the Homeric Hymns collection, in order to find out the particularities and innovations of the rereading of Alegría. We specify the characters and contents chosen by the poet, and the images and details that she has used, as well as the objectives achieved. Further more, we contextualize this poem in the work of Claribel Alegría, looking for common topics. So, we offer a complete vision of the tradition that this poem renews, not studied until now.

KeYworDs: Hymn, Myth, Rereading, Demeter, Persefone.

\section{INTRODUCCIÓN}

Claribel Alegría podría, por su biografía, haberse considerado ciudadana del mundo, pero siempre le han acompañado los fantasmas de su familia y de su tierra, o, mejor, sus tierras. Clara Isabel Alegría Vides nació en Nicaragua en 1924, pero su niñez transcurrió en El Salvador, desde los nueve años. En su juventud, fue discípula de Juan Ramón Jiménez en Washington. Entre las diversas ciudades de España y América en las que vivió con su marido Darwin J. Flakoll, destacaremos Deyá, en Mallorca (Guerrero Guerrero, 2017, pp. 95-107). Allí fue vecina de Robert Graves, que volvía del mercado cuando un día le gritó, desde el tejado que estaba arreglando, martillo en mano, “¿Es usted Robert Graves?”(Ramírez, 2018).

Alegría transmite tal aparente sencillez de lenguajes y formas que parecería que explorara la mitología grecolatina de forma casual. Sin embargo, se trata de un recurso que le permite alcanzar una serie de objetivos, como demostraremos. El poema que nos ocupa se titula "Ira Demetrae" y es el tercer poema del libro Mitosy delitos (2008). En este libro, Alegría ha retomado poemas ya publicados, junto a otros inéditos. Así, pertenece a la carpeta "Mitos" que conservamos en el archivo de Princeton (Philadelphia Area Consortium of Special Collections Libraries, s.f.)., donde, en dáctilo-escritura, se recogen 16 poemas de su producción anterior. Entre ellos, se encuentra "Ira Demetrae". Pero en el libro, gracias a la temática común, se reconfigura cada mito en conversación con los demás. Este poema siempre se ubicó en los diversos ordenamientos que llevó a 
cabo la autora al principio del libro, y, además, encontramos en sus archivos su traducción al inglés, lo cual demuestra el interés que tenía para su autora (Balladares, 2014, p. 247).

Esperamos paliar con este acercamiento, al menos parcialmente, la falta de estudios sobre la obra de Alegría, en general, y sobre la explotación de la mitología clásica en ella, más concretamente, como demuestra la bibliografía recogida por Guerrerro Guerrero (2017, pp. 89-93).

\section{La BúsQueda de DemÉter}

"Ira Demetrae" es una renovación sobre el Himno homérico a Deméter. A partir de lo que se nos cuenta en ese texto, la poeta configura la búsqueda, la constatación de la pérdida, y las consecuencias violentas del dolor. El título es programático: "Ira Demetrae" en latín, se forma sobre "Ira Dei", la ira de Dios. La fuerza de esta referencia se constatará al final del poema, donde se concretarán las consecuencias destructoras de esa ira. Alegría nos coloca, con este título, en la antigua pregunta de por qué ocurren cosas negativas, y cuál es el papel divino para no evitarlas y la culpa humana en ellas. El motivo de la cólera divina en contraste con la imagen del dios misericordioso preocupaba al cristianismo desde sus orígenes (Otón Sobrino, 2000). Antes de eso, en la mitología grecolatina y la literatura que la explota, recordemos que la cólera del héroe Aquiles es el punto de partida de la considerada como la primera obra literaria, la Iliada homérica, que en sus primeros versos nos remite a esa "cólera funesta que ojalá perezca" (Ilíada 1.1-2). En el poema que nos ocupa, "Ira Demetrae", Alegría explora las motivaciones para la cólera de Deméter y sus consecuencias. Para ello, la acompañamos en su peregrinación en busca de su hija Perséfone, que es el tema del Himno homérico a Deméter.

La colección de los Himnos homéricos es una unión de elementos muy variados. Abarca tan diversas épocas como desde los siglos VIII-VII a.C. al siglo VIII d.C., en el que se dató el Himno VIII, finalmente atribuido a Proclo (West, 1979). Además, los poemas tienen diferentes extensiones y diferente cercanía a la épica o la lírica. Por todo ello, nos centraremos en el Himno homérico a Deméter, que es la referencia para Claribel Alegría. Se trata de un texto largo, de casi quinientos versos, que se caracteriza porque aúna la tradición épica con elementos pertenecientes al ritual de Eleusis, resultando así una conjunción de gracia y gravedad (Richardson, 1974, p. 56). Podemos determinar las siguientes partes y contenidos en el poema: rapto de Perséfone (vv. 1-39); Deméter busca a Perséfone (vv. 40-304); el juicio de Zeus y la vuelta de Perséfone (vv. 305-470). Los versos finales (vv. 471-495) incluyen la institución de los misterios y la invocación final.

En cuanto a la estructura de "Ira Demetrae", el poema se divide en cuatro partes, que corresponden a cuatro monólogos de tres personajes míticos. Deméter abre y cierra el poema (vv. 1-33 y 64-109). Entretanto, Hécate le da información sobre lo ocurrido (vv. 34-51) y Hermes le proporciona una supuesta reparación (vv. 52-64). Sin embargo, como esta no es total, los últimos versos desatan la cólera divina. Además de la conjunción de lo narrativo y lo lírico, debemos hablar también del uso del monólogo dramático en la poesía, ya que los personajes míticos toman la palabra (Pérez Parejo, 2007). En cuanto a la estructura del poema y su contenido, sigue de cerca el Himno homérico a Deméter. Este Himno es nuestra fuente principal para la historia del rapto de Perséfone, que también han desarrollado Ovidio (Fastos 4.419-618 y Metamorfosis 5.346-671) y, por supuesto, Claudiano, El rapto de Proserpina.

Claribel Alegría es una poeta culta y ávida lectora, además de traductora. Pero para su acercamiento a la mitología clásica tiene un intermediario de excepción, su vecino en Deiá, Robert Graves, que le desveló su condición de hamadriade, de tal manera que tras su muerte habitaría en un árbol que debía escoger (Castellón, 2012, p. 35-36). Mitos y delitos, el libro donde encontramos casi a manera de presentación el poema de "Ira Demetrae", está dedicado "A Rubén Darío y a Robert Graves, que me enseñaron a amar los mitos”, y, además “A Juan Ramón Jiménez, mi maestro” (Alegría, 2008, p. 7). Junto a su marido, y a instancias del propio Graves, Claribel tradujo para la editorial Lumen Cien poemas (Graves, 1982).

Por todos estos motivos, en nuestra metodología analizaremos el poema de Claribel Alegría a partir no sólo de su relación con el Himno homérico y las fuentes grecolatinas, ya que nuestro punto de vista es cómo 
lo ha renovado, sino también a partir del relato que realiza Graves en Los mitos griegos (Graves, 2012), para determinar si esta influencia ha sido decisiva en sus puntos de vista. Además, hemos buscado relacionar los temas planteados con otras referencias en su poesía, de manera de contextualizar este poema en la obra de Claribel Alegría. Dejaremos, sin embargo, para mejor ocasión la parte más personal, la que tiene que ver con la búsqueda del ser querido, que la poeta emprende en sus últimos libros, desde Saudade (1999), que comienza con una cita de San Juan de la Cruz y el poema titulado "Salí a buscarte". Además, consideramos que es más relevante la ira de la diosa que la búsqueda, como demostraremos.

El primer monólogo de "Ira Demetrae" corresponde a Deméter, y trata de la búsqueda. Se especifica con "Deméter habla" a manera de acotación teatral. Su alocución consta de 33 versos y está marcada por la reiteración de una especie de estribillo de dos versos: “¿Dónde Core / dónde estás?” que abre y cierra el discurso (vv. 1-2 y 32-33) y, además, le proporciona ritmo y cohesión en medio (vv. 16-17). Es significativo que se use el nombre de "Core", pues, aparte de que por motivos de métrica y eufonía pudiera excluirse "Perséfone", no debemos olvidar que "Core" significa "doncella", de modo que se utiliza el genérico. De hecho, Deméter y Perséfone son nombradas como "Las Diosas”, simplemente. Perséfone podría también relacionarse con un cambio de nombre correspondiente al cambio de estatus como reina de los infiernos (Graves, 2012, p. 84). En cualquier caso, Perséfone se convierte en la universalización de la joven violada (cf. Fernández Díaz-Cabal, 2019), de modo que el uso de un término genérico es adecuado.

En estos versos de Alegría, Deméter explica su peregrinaje y nos proporciona algunos datos que corroboran la relación con el Himno homérico a Deméter, como la peregrinación que transcurre durante 9 días (Himno, 47):

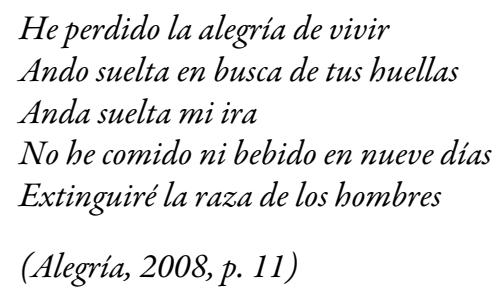

Búsqueda y tristeza, que se convierten en un sentimiento más destructivo, se van conjugando en estos versos. La diosa amenaza, adelantando el final del poema, pues advierte "anda suelta mi ira" (v. 6) y "extinguiré la raza de los hombres" (v.8). Esta anticipación de los males que prepara contra los hombres es interrumpida por Hécate.

En la segunda parte, Hécate proporciona información a Deméter. En 17 versos, encontramos la respuesta, en la que explica cómo oyó las siguientes palabras de Perséfone: "rapto rapto". Responden, por tanto, a los dos versos que han enmarcado la primera parte del poema, en los que la madre llamaba a su hija. La cercanía con su referente se confirma con datos. Su descripción de lo ocurrido se corresponde con su precedente. En primer lugar, Hécate no ve a Perséfone, sólo la escucha (vv. 34-37; Himno 22-27). Además, encontró flores dispersas, pues Perséfone fue raptada mientras cogía flores (vv. 39-40; Himno 6-15) y, finalmente, propone a Deméter ir a preguntar a Helios, "el que todo lo ve" (vv. 42-44; Himno 59-89) para poder descubrir al raptor. Ahora bien, existe una innovación fundamental: no hay narrador en el poema de Alegría, de modo que aquí Hécate es la encargada de proporcionar datos, como la recogida de flores o el conocimiento del Sol, y habla en primera persona, al igual que Deméter en los versos anteriores.

La cercanía en estos detalles con el relato proporcionado por Robert Graves en The Greek myths (2012) es manifiesta. Esto no quiere decir que necesariamente ésta sea la única fuente para Alegría, pero sí parece haber determinado cuáles son las particularidades que ha decidido recoger en su versión. Así, nos cuenta Graves:

She sought Core without rest for nine days and nights, neither eating or drinking, and calling fruitlessly all the while. The only news she could get came from old Hecate, who early one morning had heard Core crying 'A rape! A rape!' but, on hurrying to the rescue, found no sign of her. (Graves, 2012, p. 84). 
La ira recorre todo el poema de Alegría, y Hécate muestra no sólo su empatía, sino también su enfado, pues determina que "tu ira es más que justa" (v. 44) y además advierte de que "juntas nos vengaremos" (v. 48; cf. Himno 40-44). Proporciona, además, otra información, pues propone trascender la venganza hasta "los machos cabríos / que ensucian el planeta” (vv. 50-51). El final del poema supondrá un diálogo con esta idea, esta vez en boca de Deméter.

La ayuda de Hécate toma relevancia en relación con la lectura del papel de la mujer, ya que es la bruja peligrosa, entre otros atributos de esta diosa que tiene en el mundo antiguo una compleja representación (Rocha Carvalho, 2020). La propia Hécate lo advierte así en el poema que lleva su nombre (Alegría, 2008, p. 40). Los contrastes determinan el autorretrato de la diosa, donde es virgen y prostituta, sal y sulfuro, cielo e infierno. De esa manera, resulta benéfica y maléfica. El poema "Hécate" es un estudio de los diversos papeles de la mujer en la historia: la mujer es la que da vida y la que la quita. Resulta especialmente significativo en relación con el poema de "Ira Demetrae", donde muestra su disposición para ayudar a la diosa no sólo a encontrar información, sino también a vengarse. Del mismo modo, Deméter es dulce amor maternal y cuando este le es arrebatado se transforma en destructora ira.

El tercer monólogo es de Hermes, el mensajero de los dioses. Actúa, salvando las distancias, como deus ex machina. El dios trae a la joven con su madre. Claribel Alegría le dedica a Hermes un poema en Saudade (1999), que no se ha recogido en Mitos y delitos (2008), quizá porque se refiere a un anillo del dios (Alegría, 1999, pp. 48-49). Entre sus atributos, destaca este papel de intermediario. Sin embargo, la poeta recoge un momento íntimo y no ceremonial, en el que el mensajero insta a madre e hija a dar rienda suelta a los sentimientos derivados del reencuentro: "abrázala Deméter / lloren juntas las dos" (vv. 57-58).

El cuarto monólogo nos cuenta por qué Perséfone no puede volver completamente junto a su madre y a partir de este hecho se produce el clímax, en el que la ira de Deméter tiene consecuencias para la humanidad, como ya había anunciado en la primera parte.

¿Por qué escoge Claribel Alegría un himno? El himno mezcla lo lírico y lo narrativo, de manera que, como hemos indicado, se puede acercar más al género lírico o al épico. De esta manera, Claribel puede contar una historia sin perder el tono poético. El mito le permite un referente que puede renovar y reescribir, y que conecta su obra con una larga tradición. Esto le otorga solemnidad a su discurso. Su coherencia y cohesión cuidadas, su dominio de los diversos ritmos y su reiteración de contenidos, con anticipaciones del clímax final, completan el poema.

En el Himno homérico a Deméter la diosa visita a diversos personajes, y pasa un tiempo en casa de Celéo (Himno 90-304), que es la explicación de la institución de los Misterios de Eleusis. En "Ira Demetrae", únicamente Hécate alude al encuentro con Helios y encontramos un nuevo monólogo de Hermes en la tercera parte. Éste se convierte, así, en el único personaje masculino al que Alegría otorga voz de forma directa, y parece actuar como deus ex machina. Se presenta como salvador de la muchacha raptada y parece restituir la pérdida, devolviéndola a la madre. Esto se resuelve en 11 versos, donde adelanta el problema que impedirá el final feliz, ya que se engaña cuando afirma que encontró a Perséfone "sin comer / sin beber" (vv. 55-56) e insta al reencuentro, sin saber que éste no será totalmente posible. En el Himno homérico a Deméter, ante la carestía provocada por la diosa (Himno 305-309), hay una primera mensajera, Iris (Himno 314-323), que precede a la llegada de Hermes (Himno 334-358), y una tercera mensajera, que viene después, Rea (Himno 441-470).

\section{LA IRA DE DEMÉTER}

La última parte, acotada con "El juicio de Deméter", supone un monólogo de la diosa. No asistimos, en verdad, al juicio, sino que se nos cuentan sus consecuencias. Esta parte consta de cincuenta versos. De ellos, los nueve primeros se encuentran delimitados de nuevo por un verso que se repite, esta vez con una sutil pero significativa variación: “Cómo podré aceptarlo?” (v. 63) y "Nunca podré aceptarlo” (v. 71). Deméter nos cuenta la sentencia de Zeus, consistente en que Perséfone pasará tres meses con Hades, frente a la tercera 
parte del año que señalan el Himno 445-446 y Apolodoro 1.5.3, o la mitad del año, como indican Ovidio en Fastos 4. 613-614 y Metamorfosis 5. 564-565 o Virgilio en Geórgicas 1.39. La madre increpa a la muchacha por haber probado el alimento de los muertos. Esto es relevante porque Alegría se ha detenido en el punto de vista de la raptada.

El final del poema se sustenta en una esperanza imposible, en el deseo del arrepentimiento de Zeus de su decisión, que es calificada como "doble moral". El poema piensa en un futuro utópico, en el que Deméter le pondría fin al sufrimiento humano, cuando la hija vuelva a estar con su madre para siempre "y decretemos juntas / la primavera eterna".

Deméter explicita esa consecuencia de la ira que recorre los versos del poema, la venganza a la que ya le había instado Hécate, en los últimos cuarenta versos, que constituyen, aproximadamente, el último tercio del mismo. Define el papel de los poderosos, pues "Zeus es el juez inapelable / Hades es el rey de las tinieblas" (vv. 72-73), pero ella tiene un poder mayor, como describirá. La lectura tradicional del mito señalaba que la primavera es efecto de la vuelta de Perséfone junto a su madre (así entre los estoicos, como recoge Cicerón en De la naturaleza de los dioses, II 66). Alegría no ha olvidado este particular, que explicaba la alternancia de estaciones, pero luego desarrolla una innovación.

En esta última parte, la poeta da un paso más allá de la explicación que nos proporciona el Himno homérico a Deméter. No siente Alegría esa beatitud total de la naturaleza por primavera, de modo que añade una venganza aún peor al luto invernal: "después indiferencia" (v. 99). Una vez más las repeticiones permiten estructurar los versos, algo necesario dada la amplitud del poema con "les cederé a los machos / el planeta” (vv. 79-80) y "en manos de los machos / mi jardín" (vv. 100-101). En estos 19 versos, Deméter describe los daños a la naturaleza. Se centra en su propio jardín, que, frente a la agricultura, que representa la supervivencia, se trata de la naturaleza cuidada, y, de hecho, en el mundo antiguo los jardines estaban bajo la protección de Venus, diosa del amor y de la belleza. Advierte también de la destrucción del mar, pues "regarán manchas negras / en el mar / extinguirán los peces" (vv. 75-77) y del aire, ya que "harán el aire irrespirable” (v. 78). Por tanto, el jardín, la tierra, el mar y el aire son destruidos por ese hombre que no es humano sino monstruoso, un macho cabrío, una degradación que rememora el mito de las edades del hombre. En efecto, existe una visión negativa del hombre actual y de sus hechos, presente ya desde Hesíodo en sus Trabajosy días, 106-201. Esta concepción, como demuestra Díaz López (2019) tiene una gran importancia en la constitución del pensamiento occidental. Esto se confirma por "se matarán los hombres / entre si" (vv. 90-91), que nos rememora esa terrible Edad del Hierro. Claudiano (Rapto de Proserpina 3. 260-268) comparaba la ira de Deméter con el comportamiento salvaje de las tigresas de Hircania cuando le roban los cachorros (Marrón, 2013). Aquí, es el ser humano el que toma rasgos propios del animal, definido por su extrema crueldad.

La violencia concreta ejercida por Hades sobre Perséfone, así pues, se ha extendido a la violencia a la naturaleza y a la violencia al hombre. Y todo simplemente por desidia, pues las pestes ya no son divinas sino “creadas por el hombre / para matar al hombre" (vv. 99-100), en contraposición a esa peste que sufrió Tebas por los errores de Edipo, con la que comienza el Edipo rey de Sófocles (vv. 1-77).

El otro punto de vista de este rapto lo proporciona la propia Perséfone en el poema "Perséfone". En sus versos, la joven describe la bajada y la necesidad de quedarse en los infiernos, de no renacer. Perséfone se convierte en raíz que va bajando "en busca de agua / de humedad" y desea "no escuchar la voz" que le insta a volver a la superficie vestida de verde. Las imágenes del cielo y ese verde al principio del poema se transforman en pasado, en "mis ayeres / que apenas sí recuerdo" (vv. 30-31). La voz de la raptada es, de esta forma, la de la que ya no puede volver. Deméter le reprocha que comiera, haciendo imposible la restitución en "Ira Demetrae" (vv. 67-70). Aquí, Perséfone certifica que ésta ya no es posible. Sin embargo, Alegría permite a la joven expresarse por medio de esas imágenes relacionadas con la raíz que busca agua, evitando lo narrativo y la referencia a la madre o el raptor para presentar una fusión con la naturaleza. Como la raíz, Perséfone es una superviviente que ha de olvidar la voz de la fertilidad, de la superficie, y limitarse a bajar. La descripción de la bajada deja a un lado los datos relacionados con el mito para convertir a Perséfone en planta. No hay 
narración ni sentimiento, simplemente un impulso que debe escuchar y que es cada vez más poderoso: "me crecía la urgencia / de seguir” (vv. 19-20). Marcia Mc Gowan explica la contraposición entre la visión de madre e hija en estos términos: "The anger of the mother is final, irrevocable, powerful. The sorrow of the daughter ist he sorrow of youth without dreams of love" (McGowan, 2004, p. 18).

Perséfone, en el poema de su nombre, explica la imposibilidad de la restitución, pasando a formar parte del catálogo de mitos poetizados por Claribel Alegría que ilustran las relaciones de los hijos con sus padres, como los dedicados a "Ifigenia" (Alegría, 2008, p. 19) y a "Faetón" (Alegría, 2008, p. 31). Si nos detenemos en los temas de "Ira Demetrae", también la maternidad resulta un tema explorado por la poeta desde el mito, con los ejemplos de "Clitemnestra" (Alegría, 2008, p. 90) o "Medea" (Alegría, 2005, p. 50). En cuanto a la acción del hombre, "Clamor de Gaia" (Alegría, 2008, p. 93) incide sobre la destrucción.

La violencia contra la mujer es una de las preocupaciones de Alegría, que se suma a la denuncia de este problema, especialmente significativo en el mundo hispanoamericano. En este contexto, resulta necesario proporcionar voz. Daremos dos ejemplos de cómo lo consigue: el libro No me agarran viva y el poema "La Malinche”. En 1983, publica junto a su marido Darwin Flakoll el retrato de una guerrillera salvadoreña, a la que nombra Eugenia, que se convierte en una heroína construida a partir de testimonios sobre la vida real de Ana María Castillo Rivas (Ferro Sardi, 2005). En la poetización del testimonio, destacamos la autodefensa de "La Malinche" (Alegría, 2008, p. 43), la nativa ofrecida al conquistador, que se convirtió en intérprete y compañera de Hernán Cortés. La violación la desvincula de su supuesta patria, y más allá de su papel de mediadora y de creadora de una cultura mestiza, coincidimos con Octavio Paz en que "no me parece forzado asociarla a la Conquista que fue también una violación, no solamente en el sentido histórico, sino en la carne misma de las indias" (Paz,[1950] 2009, pp. 117-124). De esta manera, la violencia contra la mujer estaría en la base misma de la construcción del mundo iberoamericano, y convertirla en protagonista y heroína permitiría sacar a la luz la verdad.

La Historia ha silenciado los episodios de violencia; el mito también ha considerado que el rapto de Perséfone no es significativo. La ira de Deméter en Alegría se desata porque Zeus ha refrendado la violación de la hija. Esta figura de autoridad "contestó políticamente que no daría ni negaría su consentimiento" (Graves, 2012, p.84). Es más, también Deméter sufre este mal. No sólo Zeus y Hades se han opuesto a la voluntad de Deméter, además, sería violada por Poseidón (Apolodoro 3.6.8; Ovidio, Metamorfosis 6.118-119). Graves simplemente alude a "after a disagree able encounter with Poseidon" (Graves, 2012, 85). La poeta centroamericana no ha recogido este particular, ni el hecho de que Hades sea el tío de Perséfone. Sin embargo, sí le interesa que Zeus haya refrendado el rapto. La ira de Deméter, por tanto, surge tanto de lo ocurrido como de la autoridad que no defiende cuando debe. Una de las lecturas posibles del poema de Claribel Alegría, que debemos dejar para profundizar en ella en mejor ocasión, es la perspectiva ecocrítica (Campos López, 2018) e incluso específicamente ecofeminista, esto es, la relación entre la explotación de la naturaleza y la explotación de la mujer (Ress, 2010). En ese contexto quizá sería también posible profundizar en la relación con los Misterios de Eleusis (Páez Casadiegos, 2007), que a primera vista no ha interesado a Claribel Alegría en su peculiar renovación del Himno homérico a Deméter en este poema de "Ira Demetrae"(Alegría, 2008, 11-14).

\section{Conclusiones}

Estableceremos ahora cuáles son las principales innovaciones introducidas por Claribel Alegría en su himno. En primer lugar, las consecuencias en la naturaleza de esa ira, cólera de Deméter que da título al poema, son en realidad fruto de la acción humana. La diosa simplemente ha permitido que éstas tengan lugar, de modo que los hombres se destruyan a sí mismos. Este argumento está relacionado con la progresiva degradación de las edades del hombre y de sus relaciones entre sí y con su entorno. Los hombres ya no son hombres, sino machos cabríos. 
Aunque los tres personajes que tienen voz en el poema son los mismos del Himno homérico, debemos leerlo en el contexto del libro Mitos y delitos (2008), donde se ha otorgado, por fin, voz a Perséfone e incluso a Hécate sobre sí misma. Por otra parte, no es la primera vez que la poeta decide proporcionar voz a la mujer que ha sufrido violencia. El poema explora otros temas recurrentes en su obra y en sus poetizaciones de la mitología grecolatina: además de la violencia sobre la mujer y el silencio, las relaciones materno-filiales, la relación entre humanidad y naturaleza, y la pérdida, el dolor y sus consecuencias.

El himno permite a Alegría aunar lo descriptivo, lo lírico y lo ritual. Proporciona, pues, una razón para las consecuencias nefastas de la acción humana sobre el mundo, partiendo del rapto a una joven y explorando por qué la violencia conduce al dolor y a la destrucción. La conciencia de la violencia sufrida por la mujer, que ya había explorado desde la perspectiva del testimonio y del testimonio novelado en su prosa, se extrapola significativamente a estos versos. El hombre bestializado resulta responsable y Deméter planea su castigo en sus propias manos: la queja desgarrada de la madre estalla en la cruel indiferencia de la diosa. La poeta trasciende a cada mujer que ha sufrido violencia, problema especialmente significativo en el entorno latinoamericano, de donde procede. La denuncia es explícita contra el poder que refrenda la violación, que la silencia o que la minusvalora. La voz de Deméter universaliza la voz de cada mujer que ha visto y experimentado la violencia, convirtiendo la conciencia lúcida en poesía lúcida. Por todo ello, consigue con "Ira Demetrae" una renovación del Himno homérico a Deméter.

\section{ReFERENCIAS}

Alegría, C. y Flakoll, D. J. (1983). No me agarran viva: la mujer salvadoreña en lucha. México: ERA.

Alegría, C. (1999). Saudade. Madrid: Visor.

Alegría, C. (2005). Soltando amarras. Madrid: Visor.

Alegría, C. (2008). Mitos y delitos. Madrid: Visor.

Balladares, M. A. (2014). Mitos y delitos de Claribel Alegría: una lectura crítico-genética de tres poemas. Revista Iberoamericana, 246, 241-254.

Castellón, B. (2012). El espíritu del bosque: sombra y alas en Claribel Alegría. Cuadernos Hispanoamericanos, 740 (febrero 2012), 35-40.

Fernández Díaz-Cabal, N. (2019). Perséfone se encuentra a la Manada. El trasluz de la violación. Madrid: Akal.

Graves, R. (1982). Cien poemas. (Trad. C. Alegría y D. J. Flakoll). Barcelona: Lumen.

Graves, R. $\left(2012 ; 1955^{1}\right)$. The Greek myths. The complete and definitive edition. London: Penguin.

Guerrero Guerrero, B. (Intro., Ed.). (2017). Aunque dure un instante. Salamanca: Ediciones Universidad de Salamanca.

Marrón, Gabriela A. (2013). Imago rapti. La ira de Ceres en Claud., Pros. III. 260-268. Emerita: Revista de lingüistica y filología clásica, 81(1), 137-150.

McGowan, Marcia P. (2004). The Poetry of Claribel Alegría: A Testament of Hope. Latin American Literary Review (32) $64,5-28$.

Otón Sobrino, E. (2000). La polémica de Arnobio y Lactancio en torno a la "ira Dei". Analecta Malacitana, 6. Recuperado de http://www.anmal.uma.es/numero6/Oton.htm

Páez Casadiegos, Y. (2007). Deméter-Perséfone. Etiología y epifanía en los misterios de Eleusis. A Parte Rei: revista de filosofia, 53. Recuperado de http://serbal.pntic.mec.es/ cmunoz11/paez53.pdf.

Paz, O. (2009; $\left.1950^{1}\right)$ El laberinto de la soledad. México: FCE.

Pérez Parejo, R. (2007). El monólogo dramático en la poesía española del XX: ficción y superación del sujeto lírico confesional del Romanticismo. Espéculo: Revista de Estudios Literarios, 36. Recuperado de http://www.ucm.es /info/especulo/numero36/monodram.html. 
Philadelphia Area Consortium of Special Collections Libraries (PACSCL). (s.f.). Claribel Alegría Papers. Recuperado de http://dla.library.upenn.edu/dla/pacscl/ead.html?fq=subject_topic_facet\%3A\%2220th\%20century\%22\&i $\mathrm{d}=$ PACSCL_PRIN_MUDD_C1363USNjP

Ramírez, S. (27 de enero de 2018). In memorian Claribel Alegría. Su majestad ha muerto. El país. Recuperado de https://elpais.com/cultura/2018/01/27/actualidad/1517078715_885232.html

Ress, M. J. (2010). Espiritualidad ecofeminista en América Latina. Investigaciones feministas, 1, 111-124

Richardson, N. J. (1974). The Homeric hymn to Demeter. Oxford: Oxford Clarendon Press.

Rocha Carvalho, T. (2020). O "Hino a Hécate" de Hesíodo. Codex: Revista de Estudos Clássicos, 8(1),132-140.

West, M. L. (1970). The Eighth Homeric Hymn and Proclus. Class. Quart. 20, 300-304. 